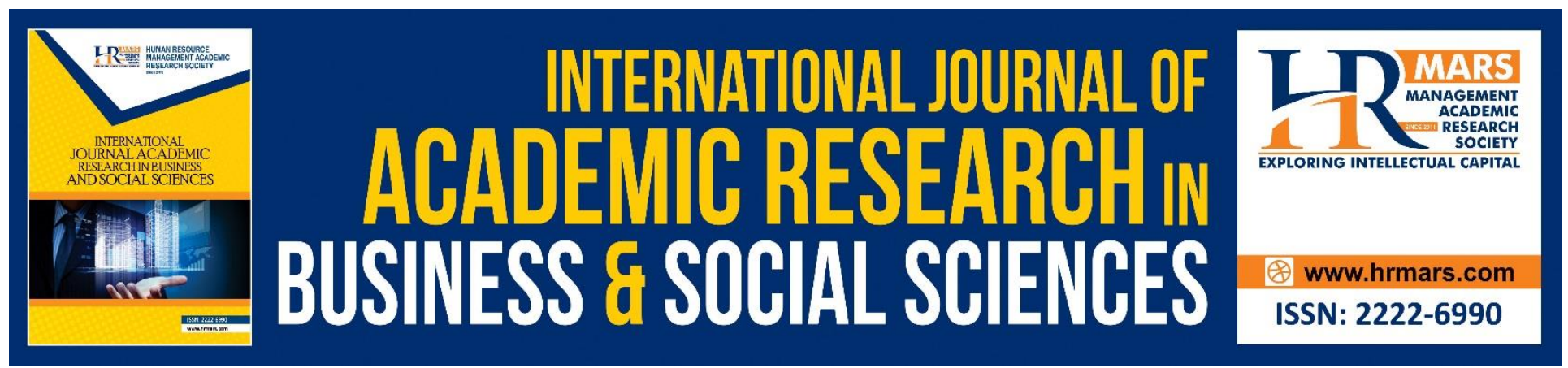

\title{
Perceived Self-Efficacy as a Mediator of the Relationship between Presenteeism and Employees' Burnout
}

Norshiba Norhisham, Norazira Mohd Abas and Siti Zaitun Saddam

To Link this Article: http://dx.doi.org/10.6007/IJARBSS/v8-i9/4656

DOI: $\quad 10.6007 /$ IJARBSS/v8-i9/4656

Received: 11 August 2018, Revised: 19 Sept 2018, Accepted: 29 Sept 2018

Published Online: 15 October 2018

In-Text Citation: (Norhisham, Abas, \& Saddam, 2018)

To Cite this Article: Norhisham, N., Abas, N. M., \& Saddam, S. Z. (2018). Perceived Self-Efficacy as a Mediator of the Relationship between Presenteeism and Employees' Burnout. International Journal of Academic Research in Business and Social Sciences, 8(9), 816-826.

Copyright: (C) 2018 The Author(s)

Published by Human Resource Management Academic Research Society (www.hrmars.com)

This article is published under the Creative Commons Attribution (CC BY 4.0) license. Anyone may reproduce, distribute, translate and create derivative works of this article (for both commercial and non-commercial purposes), subject to full attribution to the original publication and authors. The full terms of this license may be seen at: $\underline{\text { http://creativecommons.org/licences/by/4.0/legalcode }}$

Vol. 8, No. 9, September 2018, Pg. 816 - 826

Full Terms \& Conditions of access and use can be found at http://hrmars.com/index.php/pages/detail/publication-ethics 


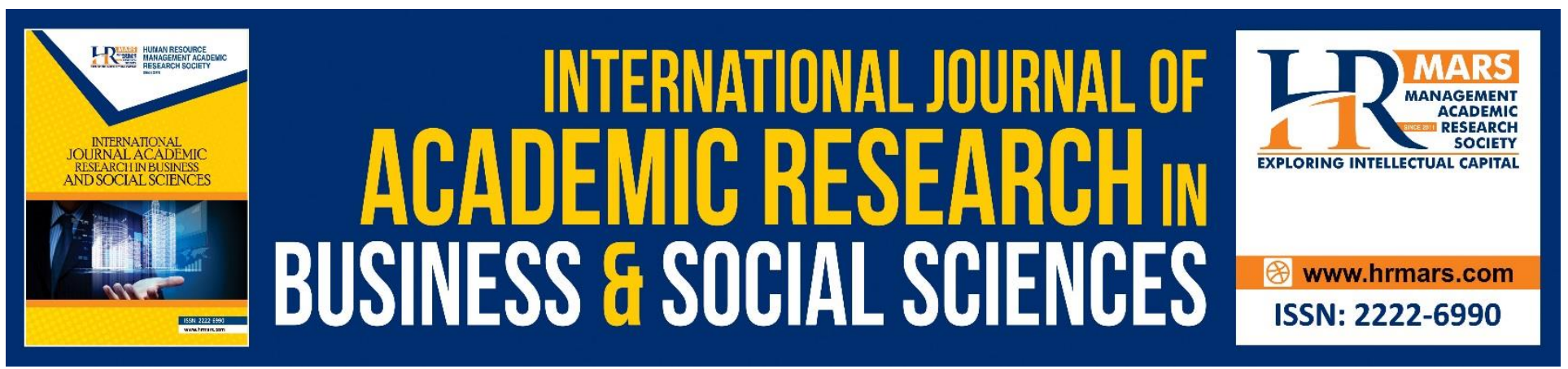

\title{
Perceived Self-Efficacy as a Mediator of the Relationship between Presenteeism and Employees' Burnout
}

\author{
Norshiba Norhisham ${ }^{1}$, Norazira Mohd $\mathrm{Abas}^{2}$ and Siti Zaitun \\ Saddam ${ }^{2}$ \\ ${ }^{1}$ Universiti Teknologi Mara Kampus Melaka (shibahisham@melaka.uitm.edu.my) \\ 2Universiti Teknologi Mara Kampus Melaka (aziraabas@melaka.uitm.edu.my) \\ 33niversiti Teknologi Mara Kampus Melaka (sitizaitun@bdrmelaka.uitm.edu.my)
}

\begin{abstract}
Employees' well-being is crucial for employers to take care of as the condition of employees could always translate into work performance. Presenteeism has received an increasingly attention from practitioners and researchers due to constant debate whether the act of coming to work despite being ill; would contribute a positive or negative impact for the employers. There exist notions that suggest that constant presenteeism could lead to employees' burnout. However, this paper discusses the role of perceived self-efficacy as mediator to the relationship between presenteeism and burnout.
\end{abstract}

Keywords: Presenteeism, Burnout, Perceived Self-Efficacy, Performance, Employee

\section{Introduction}

Absenteeism, generally defined as not showing up for scheduled work (Johns, 2010) has a long history, due to in part to its cost to organization. Presenteeism, on the other hand, is currently the subject of interest among practitioners and researchers as it is starting to represent a "silent" but significant drain on productivity (Demerouti, Le Blanc, Bakker, Schaufeli \& Hox, 2008). Majority of existing literature labels presenteeism as a negative phenomenon, claiming that employees often demonstrate lower levels of performance and productivity when they attend work while ill (Lu, Peng, Lin and Cooper, 2013). Edington and Burton (2003) estimates that presenteeism accounts to approximately $60 \%$ of the total cost of health care, while the remaining $40 \%$ is attributable to disability, absenteeism and medical/pharmacy costs. Burton et al., (1999) in Biron et al. (2006) demonstrated that productivity losses are mainly attributable to presenteeism, rather than scattered and short-term disability absences. In a long-term perspective of evaluating the costs of presenteeism, the consequences on workers' health also must be considered. A study by Kivimaki, 
Leino-Arjas and Kaila-Kangas (2005) showed that working while ill increases the risk of coronary events. Indeed, by taking time off work, people who are ill or distressed allow themselves to recover from the illness. The same applies to recovering from work during leisure time for all employees, regardless of their health. Kivimaki et al. (2005) demonstrated that chronic lack of recovery from work during leisure time increases the risk of mortality due to cardiovascular diseases. Moreover, Stewart, Ricci and Chee (2003) have shown that most lost productivity time costs related to depression can be explained by reduced performance while at work.

\section{Problem Statement}

Presenteeism; an act of employees attending work while being sick (Qin, Martinez, Ferreira and Rodriques, 2016), has attracted an increasing attention among practitioners as well as researchers (Aronsson, Gustafsson and Dallner, 2000; Hemp, 2004; Whitehouse, 2005; Johns, 2010; Rainbow and Steege, 2017). Though some scholars agree that presenteeism can be seen as employee's commitment or a type of organizational citizenship behaviour (Demerouti et al., 2009), Hemp (2004) argued that presenteeism (the problem of workers' being on the job however due to illness or other medical conditions, is not fully functioning) can cut individual productivity by one-third or more. Presenteeism is claimed to cause much more aggregate productivity loss than absenteeism (Johns, 2010) and the idea that managing presenteeism effectively could be a distinct source of competitive advantage (Hemp, 2004). Qin et al. (2016) also assumed that presenteeism always have negative consequences thus need to be reduced - if not eliminated.

The importance in studying factors that leads to burnout is supported by Yildirim et al., (2014) who suggested burnout syndrome as a situation preventing efficiency. Burnout is also considered as a critical issue for organizations and has a very important effect on not only productivity but also sustainability (Kahn, Schneider, Jenkins-Henkelman and Moyle, 2006). Therefore, Dainbow et al. (2017) and Demerouti et al. (2008) proposed on the effect of presenteeism towards burnout. Apparently, only a handful of studies have examined the cause for presenteeism yet virtually no study has been conducted to examine its consequences (Bakker et al., 2007). Yildirim, Saygin and Uguz (2014) emphasised that the repercussion and the need to identify the consequences of presenteeism should be examined as it has gained a lot of attention and its affect the cognitive energy of employees. Two most mentioned subsequent events by presenteeism are work productivity (Qin et al., 2016) and job burnout (Bakker et al., 2007; McGregor et al., 2016). Undeniably, there are serious effects on presenteeism towards the productivity of employees (Qin et al., 2016).

Majority of the studies on presenteeism are among employees in the health care industry such as nurses and pharmacists which leads to the assumption that their work would be compromised due to illness and fatigue (Demerouti et al., 2008). However, it is empirically suggested that job burnout brings more impact in employees' total quality of life (Demerouti et al, 2008), therefore the need to look at how presenteeism affect job burnout in the long run is equally important. 
INTERNATIONAL JOURNAL OF ACADEMIC RESEARCH IN BUSINESS AND SOCIAL SCIENCES

Vol. 8, No. 9, Sept. 2018, E-ISSN: 2222-6990 @ 2018 HRMARS

\section{Literature Review}

a) Presenteeism

Presenteeism - the act of showing up for work when one is ill (Johns, 2010) has witness a rise in attention from practitioners and researcher. Unlike absenteeism which has long been a preoccupation of organizations and one of the oldest research topics in the field of work and organization psychology (Johns, 2010), presenteeism is argued as the proof of employees' commitment or a type of organizational behaviour (Demerouti et al., 2009), therefore the attention through it has just arise recently.

There are several reasons why employees go to work while they are ill which includes perceived pressure from colleagues to not let them down and cause them more work, a "trigger point" system providing incentives for attendance, the fear that sick leave will put promotion opportunities at risk, and the fear of dismissal (Grinyer and Singleton, 2000). However, Roe (2003) disputed on the motives of presenteeism, where he claimed that there are also positive reasons why people continue to work when they could stay at home sick, for example, interesting and stimulating work and good relationships with colleagues and clients. Presenteeism also seems to be dependent on the type of health complaints employees experience, i.e. whether the complaint is serious enough to be considered as a legitimate excuse to stay at home sick (Demerouti et al, 2008).

Presenteeism is considered as risk behaviour for employees because by repeatedly postponing sickness leave that may effectively resolve minor illnesses, more serious illnesses may develop (Grinyer et al, 2000). Moreover, Roe (2003) has argued that presenteeism may have negative consequences for organizations in two ways; (1) individual performance may suffer since sick employees may only be able to produce the same output as healthy colleagues by investing more time or effort and (2) collective performance may suffer because workers become involved in helping sick colleagues, or because sick employees may pass on infectious illnesses to their colleagues and clients.

\section{b) Burnout}

Yener et al. (2013) defines burnout as the cause to fail, wear out, or become exhausted especially from overwork or overuse. Maslach, Schaufeli and Leiter (2001) defines burnout multifaceted syndrome of emotional exhaustion, depersonalization, and reduced personal accomplishment. It represents a chronic ongoing reaction to one's work and a negative affective response to prolonged stress (Shirom and Melamed, 2005), which is not immediately reversible after changes in tasks or the working conditions and by adequate recuperation. Kant, Jansen, Van Amelsvoort, Mohren and Swaen (2004) found in their longitudinal epidemiological study among representative sample over 12,000 Dutch employees that estimated the average duration of severe burnout to be about 2.5 years.

According to Demerouti et al. (2001), Maslach's (1982) original definition of burnout (emotional exhaustion, depersonalization, and reduced personal accomplishment) restricts the syndrome to the human services. In other words, to professionals who work in job where the primary process consists of processing people, rather than things or information. Recently Schaufeli, Lefter, Maslach and 
Jackson (1996) added three more dimensions to burnout; labelled exhaustion, cynicism and professional efficacy. This newly constructed dimensions of burnout are to determined burnout in accordance to feelings when processing other than people, namely things, information or events.

Burnout may impact the person's physical, emotional, and social life (Vladut and Kallay, 2010). Burnout appears to be quite prevalent in the developed and developing countries and probably represents considerable economic, social and psychological costs to employees and employers in these countries (Shirom, 2005). Empirical evidence has shown that burnout has important dysfunctional consequences implying substantial costs for both organizations and individuals (Yener et al., 2013). Burnout is a general term that describes the feelings of people in the helping professions who find that the stress involved in their work environment has altered their original feelings about themselves and their work. Employees experiencing these feelings of burnout can have harmful effects on their co-workers, citizens, and the reputation of the organization where they work for.

\section{c) Presenteeism with burnout}

Burnout represents a chronic ongoing reaction to one's work and a negative affective response to prolonged stress (Shirom et al., 2005), which is not immediately reversible after changes in tasks or the working conditions and by adequate recuperation. Presenteeism could be the factor leading to burnout, according to the following mechanism: when employees feel sick, their performance at work is under threat (Wright and Cropanzano, 1998). In order to reach the desired performance standards, they will use performance protection strategies (Hockey, 1993). Among the strategies that employees can use, those that are of relevance to the present study, are to invest more effort to perform as good as healthy employees and not to stay sick at home. In this way, they can try to minimize their resource losses related to their sickness.

However, sickness presence impairs physical and psychological recuperation and recovery after strain or disease. Meijman and Mulder (1998) suggest that if opportunities for recovery -, e.g. from workrelated fatigue during the non-working period - are insufficient, one's psychobiological systems remain activated and recovery to homeostatic levels may not be achieved. The employee, who is still in a sub-optimal state, will thus have to make additional (compensatory) efforts during the next working period. As a result, negative load effects accumulate, leading to a further draining of one's energy, and chronic fatigue or even a to a total breakdown. Thus, presenteeism; because of its potential for reducing recovery, is likely to lead to higher levels of exhaustion in the long run. Alternatively, sickness absence could be health-promoting since it would facilitate recuperation following strain or disease (Aronsson et al., 2005). Moreover, because of inadequate recuperation, employees may develop negative attitudes towards their work, thus develop depersonalization over time (Fritz and Sonnentag, 2005).

While there is no empirical evidence yet that presenteeism leads to burnout, there are suggestions that sufficient recovery during the weekend decreases burnout complaints and fosters general wellbeing after the weekend (Fritz et al., 2005). Thus, staying away from work positively contributes to 
INTERNATIONAL JOURNAL OF ACADEMIC RESEARCH IN BUSINESS AND SOCIAL SCIENCES Vol. 8, No. 9, Sept. 2018, E-ISSN: 2222-6990 @ 2018 HRMARS

the reduction of burnout (Demerouti et al., 2009). The only study that shows the effects of presenteeism on health is the eight-year prospective study of Kivimaki et al. (2005) among male civil servants. Therefore, it is believed that working while ill may produce a cumulative psychological burden with psycho-physiological consequences.

d) The mediating role of perceived self-efficacy in burnout

Job burnout is a concept that can be considered as a symptom of emotional exhaustion that was commonly observed among individuals (Yu, Wang, Zhai, Dai and Yang, 2014). Generally it is an extreme reaction that individuals experience when they cannot successfully cope with work pressure (Yu et al., 2014). The antecedents of job burnout have been an interest to scholars and researchers as to what makes employees feel a particular pressure when they are working. Burnout has been linked to work ability (Hanaken, Bakker and Schaufeli, 2006), mental health (Liu and Wang, 2004), perfectionism (Stoeber and Rennert, 2008), emotional regulation (Tsouloupas, Carson, Matthews, Grawitch and Barber, 2010), and job satisfaction (Fisher, 2011) and burnout has been the cause of employees' turnover (Chan, 2006).

The relationship between self-efficacy and burnout has widely studied specifically among teachers. Classroom management self-efficacy (CMSE) which acts as a sub-component of teacher self-efficacy (TSE) (Tschannen-Moran and Woolfolk-Hoy, 2001), can be seen as a protective factor against the psychological and physical feelings of burnout among teachers (Aloe, Amo and Shanahan, 2014). Skaalvik and Skaalvik (2007) structural equation modelling found a strong relation between teacher self-efficacy and teacher burnout. Self-efficacy and burnout are not only limited to a direct negative relationship but self-efficacy also has been suggested to mediate the relationship of burnout with other predictors (Aloe et al., 2014). Yu et al. (2014) in their research on mediating role of self-efficacy between work stress and burnout among teachers found that self-efficacy can mediate the effect of pressure on job burnout, where it represents the faith of teachers toward their teaching ability.

According to Wright and Cropanzano (1998), it is possible to understand presenteeism as the relevant indicator leading to burnout. Employees who attend work despite being ill are prone to emotional exhaustion; when they couldn't perform their task due to feeling ill. Nevertheless, the relationship between presenteeism and job burnout can be influenced by mediating variables, as may be the case for perceived self-efficacy. Sense of self-efficacy is related to the three dimensions of job burnout. For example, high perceived self-efficacy is related to low emotional exhaustion, high personal accomplishment and low depersonalization (Skaalvik and Skaalvik, 2010).

Thus, perceiving a situation as threatening will depend on the way the individual interprets that situation and coping skills. In this sense, taking into account the importance of perceived self-efficacy in promotion and maintenance of emotional well-being, it is proposed that self-efficacy takes on mediating role between presenteeism and job burnout. Those individuals with higher self-efficacy will assess, affectively, their lives as better, even when they need to present at work while being ill. 
INTERNATIONAL JOURNAL OF ACADEMIC RESEARCH IN BUSINESS AND SOCIAL SCIENCES

Vol. 8, No. 9, Sept. 2018, E-ISSN: 2222-6990 @ 2018 HRMARS

\section{Research Framework}

The variables of this study are presenteeism (independent variables), perceived self-efficacy (mediating variable) and burnout (dependent variable)

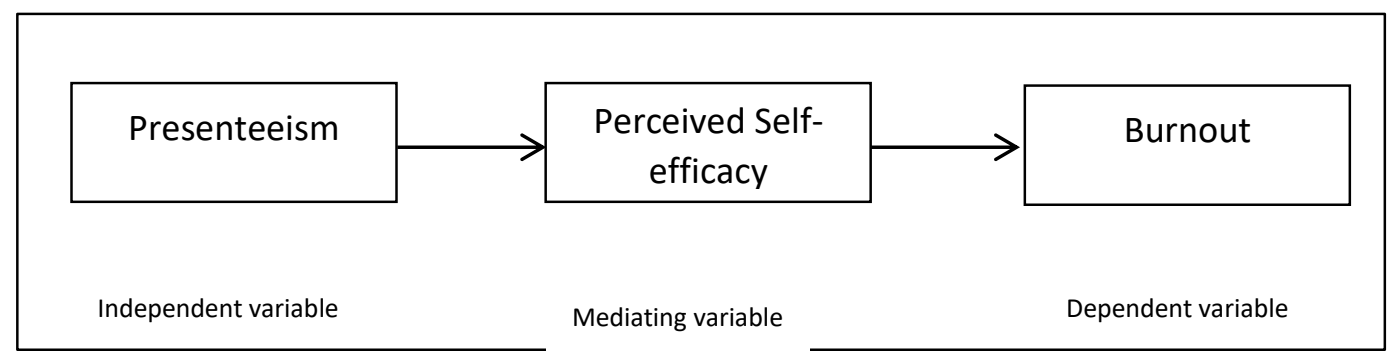

Figure 1: Research framework

\section{Conclusion}

There are numerous assumptions among the workplace is that employees who are in attendance are the best employees, regardless of their current situation. Presenteeism is always associated to the fear of causing colleagues perform extra tasks, policies that provide incentives for attendance, putting promotion opportunities at risk, and fear of dismissal (Grinyer and Singleton, 2000; McKevitt et al., 1998). These assumptions however give significant impact towards employees' well-being, especially when they are not physically able to attend to work thus leading to sickness and burnout.

When employees are unwell, their performance at work is under threat (Wright and Cropanzano, 1998) therefore as a defense mechanism, employees tend to use performance protection strategies in order to maintain their performance standards. Among the strategies that employees use is to invest more effort in order to perform as good as healthy employees and not to stay sick at home (Bakker et al., 2009).

Meijman and Mulder (1998) suggested that if opportunities for recovery from work-related fatigue during the non-working period are insufficient, then recovery is not achieved (also known as sustained activation). The employee, who is still in a sub-optimal state, will have to make additional (compensatory) efforts during the next working period. As a result, negative load effect is accumulated leading to a further draining of one's energy, and chronic fatigue or even a to a total breakdown. Therefore presenteeism, because of its potential for reducing recovery, is likely to lead to higher levels of exhaustion in the long run. Alternatively, sickness absence could be healthpromoting since it would facilitate the recuperation of strain or disease (Aronsson and Gustafsson, 2005). Inadequate recuperation may result to employees developing negative attitudes towards their work thus develop depersonalization over time (Sonnentag, 2005).

Self-efficacy has been hypothesized to influence choice of behavioral activities, effort expenditure, persistence in the face of obstacles and task performance (Multon, Brown and Lent, 1991). Therefore, the relationship between presenteeism and burnout may be influenced by mediating variables, as may be the case for perceived self-efficacy. 
INTERNATIONAL JOURNAL OF ACADEMIC RESEARCH IN BUSINESS AND SOCIAL SCIENCES Vol. 8, No. 9, Sept. 2018, E-ISSN: 2222-6990 @ 2018 HRMARS

The intention of this paper is to create awareness among employers and employees of the effects of presenteeism and dispute the assumptions of absent employees due to sickness are underperformed employees. It is also meant to create a working environment that encourage employees to take a break when needed so they are able to return refreshed and productive. 
INTERNATIONAL JOURNAL OF ACADEMIC RESEARCH IN BUSINESS AND SOCIAL SCIENCES

Vol. 8, No. 9, Sept. 2018, E-ISSN: 2222-6990 @ 2018 HRMARS

\section{References}

Aloe, A. M., Amo, L. C., \& Shanahan, M. E. (2014). Classroom Management Self-Efficacy and Burnout: A Multivariate Meta-Analysis. Educational Psychology Review, 26, pp. 101-126.

Aronsson, G., \& Gustaffon, K. (2005). Sickness presenteeism: prevalence, attendance-pressure factors, and an outline of a model for research. Journal of Occupational \& Environmental Medicine 47 (9) pp.958-966.

Aronsson, G., Gustafsson \& K, Dallner, M. (2000). Sick but yet at work: an empirical study of sickness presenteeism. Journal of Epidemiology and Community Health 54 pp.502-509.

Bakker, A. B., \& Demerouti, E. (2007). The Job Demands-Resources model: state of the art. Journal of Managerial Psychology. Vol. 22. Issue 3. pp. $309-328$.

Bakker, A. B., Demerouti, E., Boer, E. D., \& Schaufeli, W. B. (2003). Job demands and job resources as predictors of absence duration and frequency. Journal of Vocational Behaviour 62. pp. $341-$ 356.

Biron, C., Brun, J.P., Ivers, H., and Cooper, C. (2006). At work but ill: psychosocial work environment and well-being determinants of presenteeism propensity. Journal of Public Mental Health. Vol. 5. Issue 4. pp.26-37.

Brauchli, R., Schaufeli, W. B., Jenny, G. J., Fullemann, D. \& Bauer, G. F. (2013). Disentangling stability and change in job resources, job demands, and employee well-being - a three-wave study on the JDR model. Journal of Vocational Behaviour 83. pp. $117-129$.

Caverley, N., Cunningham, J. B. \& MacGregor, J. N. (2007). Sickness Presenteeism, Sickness Absenteeism, and Health Following Restructuring in a Public Service Organization. Journal of Management Studies, 44(2), $304-319$.

Chan, D. W. (2011). Emotional intelligence and components of burnout among Chinese secondary school teachers in Hong Kong. Teaching and Teacher Education, 22(8), 1042-1054.

Cunningham, J. B., Gardner, E. M. (2007). Power, effect and sample size using GPower: practical issues for researchers and members of research ethics committees. Evidence Based Midwifery 5. pp. 132-136.

Demerouti, E., Bakker, A. B., Schaufeli, W. B. \& Nachreiner, F. (2001). The JDR model for burnout. Journal of Applied Psychology. Vol. 86, No. 3, pp. $499-512$.

Demerouti, E., Le Blanc, P., Bakker, A. B., Schaufeli, W. B. \& Hox, J. (2008). Present but sick: a threewave study on job demands, presenteeism and burnout. Career Development International. Vol. 14. No. 1, pp. $50-68$.

Goffman, E. (1963). Stigma: notes on the management of spoiled identity. Penguin Books, PrenticeHall Inc., NJ

Grinyer, A. and Singleton, V. (2000) Sickness Absence as Risk-Taking Behaviour: A Study of Organisational and Cultural Factors in the Public Sector. Health, Risk \& Society, 2, 7-21.

Feng, L., Li, J., Xiang, Y. \& YogJuan, L. (2012). Job demands, job resources and safety outcomes: the roles of emotional exhaustion and safety compliance. Accident Analysis and Prevention 51. pp. $243-251$

Fisher, M. H. (2011). Factors Influencing Stress, Burnout, and Retention of Secondary Teachers. Current Issues in Education, 14(1) 
INTERNATIONAL JOURNAL OF ACADEMIC RESEARCH IN BUSINESS AND SOCIAL SCIENCES

Vol. 8, No. 9, Sept. 2018, E-ISSN: 2222-6990 @ 2018 HRMARS

Fritz, C \& Sonnentag, S. (2005). Recovery, Health, and Job Performance: Effects of Weekend Experiences. Journal of Occupational Psychology 10. Vol. 3. pp. $187-199$.

Gillbreath, B. \& Karimi, L. (2012). Supervisor behavior and employee presenteeism. International Journal of Leadership Studies. Vol. 7. Issue. 1. pp. $114-131$.

Grinyer, A. and Singleton, V. (2000) Sickness Absence as Risk-Taking Behaviour: A Study of Organisational and Cultural Factors in the Public Sector. Health, Risk \& Society, 2, 7-21.

Hanaken, J. J., Bakker, A. B., \& Schaufeli, W. B. (2006). Burnout and work engagement among teachers. journal of School Psychology. Issue. 43. pp. $495-513$.

Hemp, P. (2004). Presenteeism: at work - but out of it. Harvard Business Review.

Hilton, T. L. \& Patrick, C. (1969). Cross-sectional versus longitudinal data: an empirical comparison of mean differences in academic growth.

Johns, G. (2010). Presenteeism in the workplace: a review and research agenda. Journal of Organizational Behaviour 31. pp. $519-542$.

Kahn, J. H., Schneider, K. T., Jenkins-Henkelman, T. M., \& Moyle, L. L. (2006). Emotional Social Support and Job Burnout Among High-School Teachers: Is It All due to Dispositional Affectivity? Journal of Organizational Behavior, 27(6), 793-807.

Lu, L., Peng, S-Q., Lin, H. Y., \& Cooper, C. L. (2013). Presenteeism and health over time among Chinese employees: The moderating role of self-efficacy. An International Journal of Work, Health \& Organisations. Vol. 28. pp. $165-178$.

Maslach, C., Schaufeli, W. B., \& Leiter, M. P. (2001). Job Burnout. Annual Review Psychology 2001. Vol 52. pp. 397-422

McGregor, A., Magee, C. A. \& Caputi, P. (2016) A job demands-resources approach to presenteeism. Journal of Career Development International. Vol. 21. No. 4, pp. $402-418$.

Multon, K.D., Brown, S.D., \& Lent, R.W. (1991). Relation of self-efficacy beliefs to academic outcomes: A meta-analytic investigation. Journal of Counseling Psychology, 38, 30-38.

Olsen, C. \& St. George, D. M. M. (2004). Cross-Sectional Study Design and Data Analysis.

Qin, Z., Martinez, L. F., Ferreira, A. I. \& Rodrigues, P. (2016). Supervisor support, role ambiguity and productivity associated with presenteeism: a longitudinal study. Journal of business research 69. pp. $3380-3387$.

Rainbow, J. G. \& Steege, L. M. (2017). Presenteeism in nursing: an evolutionary concept analysis. Nursing Outlook 65. pp. 615 - 623.Schaufeli, W. B. (2015). Engaging leadership in the job demands-resources model. Journal of Career Development International. Vol. 20. Np. 5, pp. 446 $-463$.

Maslach, C., Jackson, S. E., Leiter, M. P., Schaufeli, W. B., \& Schwab, R. L. (1996). The Maslach Burnout Inventory - General Survey.

Meijman, T.F. and Mulder, G. (1998) Psychological Aspects of Workload. In: Drenth, P.J.D. and Thierry., H., Eds., Handbook of Work and Organizational Psychology, Hove, Psychology Press. 533.

Shirom, A. and Melamed, S. (2005) Does Burnout Affect Physical Health? A Review of the Evidence In: Research Companion to Organizational Health Psychology, Edward Elgar Publishing, Northampton, MA, 599-622. 
INTERNATIONAL JOURNAL OF ACADEMIC RESEARCH IN BUSINESS AND SOCIAL SCIENCES

Vol. 8, No. 9, Sept. 2018, E-ISSN: 2222-6990 @ 2018 HRMARS

Skaalvik, E. M., \& Skaalvik, M. (2007). Dimensions of Teacher Self-Efficacy and Relations With Strain Factors, Perceived Collective Teacher Efficacy, and Teacher Burnout. Journal of Educational Psychology. Vol. 99. No. 3. pp. $611-625$.

Skaalvik, E. M., \& Skaalvik, S. (2010). Teacher Self-Efficacy and Teacher Burnout: A Study of Relations. Teaching and Teacher Education. Vol. 26. pp. 1059-1069.

Stewart, W. F., Ricci, J. A \& Chee, E. (2003). Cost of lost productive work time among US workers with depression. Vol. 289. No. 23. pp. $3135-3144$.

Stoeber, J. \& Rennert, D. (2008). Perfectionism in school teachers: relations with stress appraisals, coping styles, and burnout. Anxiety, stress and coping, An International Journal.

Svhaufei, W. B. \& Taris, T. W. (2014). A critical review of the JDR model: implicaations for improving work and health. pp. $43-68$.

Tschannen-Moran, M., \& Woolfolk Hoy, A. (2001). Teacher Efficacy: Capturing an Elusive Construct. Teaching and Teacher Education, 17, 783-805.

Tsouloupas, C. N., Carson, R. L., Matthews, R., Grawitch, M. J. \& Barber, L. K. (2010). Exploring the Association between Teachers' Perceived Student Misbehaviour and Emotional Exhaustion: The Importance of Teacher Efficacy Beliefs and Emotion Regulation. Educational Psychology, Vol. 30. No. 2. pp. 173-189

Vicker, M. H. (1994). Technological solutions for those with chronic illness in the workplace: utopia, panacea or myopia? Proceeding of the Association of Management $12^{\text {th }}$ Annual International Conference. Multidisciplinary Management Group. Vol. 1, pp. $66-71$.

Vicker, M. H. (1997). Life at work with "invisible" chronic illness (ICI): the unseen, unspoken, unrecognized dilemma of disclosure. Journal of Workplace Learning. Vol. 9. Issue 7, pp. $240-$ 252.

Wright, T. A. \& Cropanzano. R. (1998(. Psychological well-being and job satisfaction as predictors of job performance. Journal of Occupation Health Psychology. Vol. 5. No. 1. pp. $84-94$.

Yang, T. Shen, Y. M., Zhu, M., Liu, Y., Deng, J., Chen, Q. and See, L. C. (2015). Effects of co-worker and supervisor support on job stress and presenteeism in an aging workforce: A SEM approach. International Journal of Environment Research and Public Health. pp. $1-15$.

Yener, M. \& Coskun, O. (2013). Using job resources and job demands in predicting burnout. Procedia Social and Behavioral Sciences 99. pp. $869-876$.

Yew, M. C. \& Chu, M. J. T. (2016) Moderating effects of presenteeism on the stress-happiness relationship of hotel employees: a note. International Journal of Hospitality Management 55. pp. $52-56$.

Yildirim, M. H, Saygin, M. and Uguz, S. (2014). Effects of presenteeism syndrome on employees' burnout levels. International Journal of Social Sciences and Humanity Studies. Vol. 6, No. 1.

Yu, X., Wang, P., Zhai, X., Dai, H., \& Yang, Q. (2014). The Effect of Work Stress on Job Burnout Among Teachers: The Mediating Role of Self-efficacy. Journal for Quality of Life Measurement. 